\title{
Does Diversity Undermine Trust and Cooperation? THEORY AND EVIDENCE
}

\section{Marco Giani* Shaun P. Hargreaves Heap ${ }^{\dagger}$ Dimitrios Minos}

Abstract. It is often argued that diversity depletes the social capital of trust and cooperation. We argue there is no compelling theoretical reason for supposing that trust and cooperation will move together in response to diversity; and we provide new causal evidence that they do not. While diversity undermines trust, we find that people in more diverse societies are, surprisingly, better able to cooperate in both new aggregate and individual level observational data and in laboratory experiments. These results caution against the suggestion that diversity creates trade-offs for society: e.g. between innovativeness and solidarity or between freedom of movement and welfare state generosity.

\footnotetext{
${ }^{*}$ Assistant Professor, Department of Political Economy, King's College London. Email: marco.giani@kcl.ac.uk.

†Professor, Department of Political Economy, King's College London. Email: s.hargreavesheap@kcl.ac.uk.

${ }^{\ddagger}$ Postdoctoral Fellow, Business School, King’s College London. Email: dimitrios.minos@kcl.ac.uk.
} 


\section{INTRODUCTION}

The ability of people to trust and to overcome the free rider problem when cooperating with each other are important determinants of a society's social capital. Respectively, they enable, for example, people to engage in market exchange and provide public goods without incurring significant transaction costs. As a result, it is important to understand what influences these abilities and why they might differ across countries (e.g. Keele, 2007; Gilligan, Pasquale, and Samii, 2013). It is in this context, that diversity within a population has attracted much recent attention (see e.g. Andersen and Paskeviciute, 2006; Hooghe et al. 2009; Carlin, and Love, 2018). In particular, it has been argued, in what is, perhaps, emerging as a conventional wisdom, that diversity undermines levels trust and cooperation in society (e.g. see Kaufman, 2017, and Collier, 2018). Of course, diversity may also bring benefits in terms of innovativeness and so the additional conclusion is also often drawn that countries may, in effect, face an innovation-solidarity trade-off as their diversity changes (e.g. see Alesina and La Ferrara, 2002; Hero, 2003; Ashraf and Galor, 2014, and Goodhart, 2013, on the 'progressive's dilemma'). That is, societies face a trade-off, it is claimed, between the likes of Sweden (with its relatively homogeneous population and notable solidarity found in a large welfare state) and countries like the US (where there is diversity, dynamism but less solidarity, as revealed by its smaller welfare state). In this paper, we argue that the conventional wisdom whereby diversity undermines trust and cooperation is only half right, with the result that the associated innovation-solidarity trade-off has been falsely drawn.

There are three parts to our argument. The first is theoretical. We argue that the theoretical reasons for supposing that trust and cooperation move together in response to diversity are weak. This leads us to conclude that whether trust and cooperation move together under the influence of diversity is an empirical matter; and we take up this challenge in the second and third parts of our argument. To put our contribution in this respect in context, there is already observational data using current data on trust, public goods provision and diversity (see e.g. Stolle, Soroka, and Johnston, 2008; Hooghe et al., 2009). Typically in this literature, diversity is negatively associated trust, but the negative association is much weaker between diversity and indexes of cooperation like public goods provision (e.g. see Putnam, 2007). It is difficult, however, in such associations to establish causation between variables because the level of diversity, like that of trust and cooperation, are likely to be endogenous. For this reason, we focus on two types of potentially stronger causal evidence. With one, we follow two recent studies that have addressed the endogeneity problem by 
using two deep, historical and so plausibly exogenous variables related to diversity that might influence current willingness to trust and cooperate: Ashraf and Galor (2014) and Enke (2018) respectively use the genetic diversity and the tightness of the historical kinship systems in a given population. They both show that these exogenous 'diversity' variables negatively affect current levels of trust, but neither consider whether they have a similar effect on measures of cooperation. We do. Moreover, our evidence refers not just to cross country aggregate variations in trust, cooperation and diversity, we are also able to provide individual level evidence. In both kinds of evidence, these exogenous indicators of diversity do not have a negative effect on contemporary cooperation. The second type of causal evidence we present comes from laboratory experiments. This is the virtue of such experiments: they can be used to identify possible causal influences. The laboratory evidence again points to diversity having a different effect on cooperation to that on trust.

Thus, we contribute to the social capital and, in particular, that part of this literature that has had an important impact on public policy debate around diversity (e.g. in relation to immigration, see Kaufman, 2018, and Goodhart, 2013). Our contribution is, as a result, important because we qualify the conventional wisdom in this policy area: diversity does not have the same influence on cooperation as trust. While we are not first to notice this (e.g. Hargreaves Heap, 2020), to our knowledge, our arguments are novel, especially in developing empirical evidence that allows stronger causal inferences to be drawn regarding the influence of diversity.

Our paper proceeds as follows. We set out next the theoretical argument for believing that trust and cooperation are not so fundamentally linked that they can be expected to move together in response to a society's diversity. Sections 3 and 4 develop the empirical evidence on the causal influence of diversity on trust and cooperation. Section 5 concludes.

\section{THEORETICAL ISSUES}

In this section, we tease apart theoretically trust and cooperation. They are commonly elided in the literature. In the highly influential A state of trust, Margaret Levi (1996) elegantly describes trust as "a holding word for a variety of phenomena that enable individuals to take risks in dealing with others, that solve collective action problems, or that promote willingness to act in ways that seem contrary to standard definitions of self-interest." Similarly, one of the best recent contribution in the field, analysing how partisanship - as a form of 
diversity - shapes trust, argues that "Interpersonal trust is perhaps the cooperative social preference most central to democratic governance because it helps resolve the collective action problems and conflicts over public and private goods that are comparatively frequent in liberal political and economic systems" (Carlin, and Love, 2018, p76).

Collier (2018) provides a similar illustration from economics where he specifies a plausible the mechanism linking diversity with trust and then projects this insight on to cooperation.

We trust people if we are confident that we can predict how they will behave. We have more confidence in our predictions if we can safely use the techniques of a 'theory of the mind': I predict your behaviour by imaging how I would behave in your circumstances. But the technique is only reliable to the extent that I am confident that we share the same belief system. If we have radically different belief systems, I cannot put myself in your shoes because I do not inhabit the mental world that shapes your behaviour. I can't trust you. The decline in trust is not the end of the unravelling of social democracy. The next rung down the ladder is the implications of decline in trust for the ability to cooperate. (p.102-3).

There are three possible theoretical reasons or mechanisms that might link trust and cooperation in lockstep in this way. We consider each in turn now and conclude that none provide a clear reason for expecting, as a matter of theory, that the two will move together in response to diversity.

\section{CoOperation CRITICALLY DEPENDS ON TRUST}

Trust could be such a critical ingredient in cooperative behavior that the level of cooperation depends on that of trust. Thus, if trust falls with diversity, so will cooperation. Trust might be such a fundamental ingredient in cooperative behaviour if it can be shown to be either a necessary and/or a sufficient condition for cooperation. This is the first argument we consider.

For trust to be a sufficient condition, it would have to be the case that if someone trusts that others will cooperate in a public goods interaction, then they will always cooperate. But this is not the case. A selfish person will not. It is in a selfish person's self-interest to free-ride in a public goods interaction by not cooperating when others do. That's the nub of this social dilemma. Indeed, this is why from a strategic perspective trust and public good games are different. It is enough in a trust game that the $1^{\text {st }}$ mover believes that the $2^{\text {nd }}$ 
mover is trustworthy (i.e. the 2nd mover will not behave selfishly and run off with whatever has been given) for a selfish $1^{\text {st }}$ mover to decide to trust the $2^{\text {nd }}$ mover. In comparison, it is not enough to induce cooperation by one player if they believe others will cooperate (i.e. not behave selfishly) in a public goods game. Something more is required to avoid free riding in the public goods game.

Trust would be a necessary condition if it was impossible to imagine cooperation occurring without each person trusting that the other will cooperate. But this, too, is not the case. Those who are guided by Kant's categorical imperative, for instance, will cooperate independently of what others do: it is a categorical imperative and not a hypothetical one. Of course, one might doubt whether such Kantians exist in practice and so cooperation without trust becomes unimaginable for this reason. But while there is evidence that much cooperation in public goods games does occur because people expect others to cooperate and they reciprocate (e.g. in laboratory public goods games, around 50\% of subjects fall into this category, see Fischbacher and Gachter, 2006), there is also evidence that people cooperate unconditionally (e.g. about 10-15\% of laboratory subjects, see Fischbacher and Gachter, 2006). Thus, trust neither seems to be a necessary nor a sufficient condition for cooperation.

\section{Trust and CoOperation have the SAME CAUSE THAT IS ACTIVATED By Diversity}

A second possible reason why trust and cooperation might be expected to move in tandem is that they have a joint cause. This seems to be what Collier has in mind above - when he connects trust with cooperation above through a shared 'theory of the mind' in such settings. Collier's theory seems to be that you project yourself into the other person's shoes and so decide what they will do with more or less confidence depending on whether you share an identity with them. It is plain from the discussion above that something more must be required of a shared identity that this to generate cooperation (e.g. a desire to reciprocate), we set this difficulty aside here because there is an additional one. This interpretation of the common cause may tie levels of trust to those of cooperation among those who identify with each other, but it breaks the connection between this shared level of trust and cooperation in a society and its diversity. This is because it does not fix the level of trust and cooperation among those who share an identity; instead it comes to depend on the character of the identities that are shared. Thus, in a homogenous society of selfish people, the level of trust and cooperation would be zero; whereas in heterogeneous society with different, say religious groupings, the level of trust and cooperation within each group would likely be high, even if 
it felt in interactions between groups.

Even if the Collier mechanism does not secure the connection between trust/cooperation and diversity. It is possible that some other joint cause might. In general, for this to be the case, situations involving trust and cooperation would have to be sufficiently similar to trigger the same motivational wellspring or decision rule. Is this so? We have already drawn attention to one important source of difference between the two types of interaction above that would count against such a general presumption: i.e. trust is neither a necessary nor sufficient condition for cooperation. In addition, there are differences in character of what trust and cooperation entail that makes a single shared cause unlikely. Trust is personal, whereas overcoming the free rider problem to engage in successful collective action is not so personal: it is more impartial and political.

Trust feels personal: the person called upon to trust another has to expose themselves to some specific other person in what is a two-person sequential interaction. You trust, if you believe the other person is trustworthy and it is easier to gauge their trustworthiness when you know something about the other person. Public goods interactions are not generally personal in this way. They usually involve more people and each person is symmetrically placed in the interaction. No one person moves before the others. Indeed, we talk about these interactions impersonally as collective action problems. The name is instructive: it is not personal or even known as an individual decision problem (although it plainly is in the sense that individual makes decisions). Instead, it is called a collective action problem. This is important because this collective action problem is first, and often best known from Hobbes's Leviathan, where he uses it to introduce a distinctive form of political decision making. He asks people in a state of nature to think, as it were, politically in the sense of constitutionally. What rules would they like to constrain everyone and so enable more effective individual actions? People will agree to rules (e.g. of mutual disarmament), he suggests, because action that is so constrained is mutually beneficial. But they need someone to enforce these rules. Thus, they give up their use of arms and cede the monopoly of force to the sovereign to enforce the rules. In this way, the public goods game sets in train a distinctive type of rule oriented or political decision making - at least for Hobbes. This is not personal. It is impersonal and ultimately pragmatic; whereas trust plausibly depends on some form of fellow-feeling that is specific to the people involved.

Nor is Hobbes alone in developing the idea that public goods game interactions might call upon a different kind of motivation to that from which trust springs. This is the argument, for 
example, in effect, that Hume also makes when he suggests that the 'artificial virtue' of justice develops to solve collective action problems in complicated societies. ${ }^{1}$ It is 'artificial' because people cannot draw on the natural virtue of sympathy (which is otherwise very important for Hume). Sympathy could operate in trust interactions where you have reason to think you know the other person, but its writ will not run to the impersonal interactions that characterize complicated and dynamic societies. For this you need the 'artificial virtue' of justice. $^{2}$

Thus, while trust and cooperation might in practice have a sufficiently strong common cause, it is not obvious why this should be expected to be the case when the character of the interactions and how we commonly think about them are different.

\footnotetext{
${ }^{1}$ Hume (1738) see Book III, Section II. Hume does not give an account of how this happens, but since what is required is a form of political, rule governed behavior, it seems likely that the political development of democracy plays a role. This seems especially likely if Mill and de Tocqueville are right in arguing that the participation in democratic decision making encourages the habits of cooperation. But this is no more than a suggestion that a second reason why cooperation arises in diverse societies is because 'necessity is the mother of invention'.

${ }^{2}$ Philosophers have sometimes distinguished for this reason between two kinds of non-selfish sources of motivation: ethics and justice. Considerations of justice arise in the discussion of the rules that govern everyone's behavior in society. They can be entirely pragmatic, as in Hobbes, or may appeal to arguments about what is fair, as in Rawls (1971). Brian Barry (1965) refers to the operation of a kind 'reasonableness' in these settings that overcomes simple self interest and, interestingly, he refers to Schelling's idea of 'salience' in this context. Although Schelling was concerned primarily with coordination problems, it is interesting because, unlike much of the subsequent development of the idea of salience, Schelling's idea of salience involved thinking about what rule to adopt. Crucially in all these cases, the rules apply to all in a society. In comparison, ethical concerns surface in personal relations and give rise to what are thought of as more distinctively empathetic or humanitarian concerns for very specific other people. You can unsurprisingly therefore care more about friends and family than strangers on these grounds, whereas rules of justice (or salience) cannot be applied more or less rigorously to some and not others in society. They would not be consistent with justice (or coordination) if this was the case. Of course, this distinction between ethics and justice can also be blurred in philosophy and so perhaps it is not surprising that some economists seem to have done the same by collapsing non-selfish motivation into a singular category of 'social preference' which waxes and wanes for both trust and cooperation. The point, however, is that this distinction exists in Western cultures and so it should not be surprising that public goods interactions can trigger a different kind of political motivation to that found in trust games. The distinction has been important in other disciplines. For example, Durkheim (1893) famously distinguished between the mechanistic solidarity found in traditional societies and the organic solidarity that arises in more complicated societies with the division of labour. Likewise, Cook and Hardin (2007), provide a recent elaboration of this distinction and Gintis (2016) is one of the few economists who does the same. We have been primed, so to speak, through our culture to see this distinction and like any prime, it will likely have effects on some people's behavior. This is the lesson of behavioural economics.
} 
The third possible reason why trust and cooperation might move in lockstep is that while they have different causes, each cause happens to entail that as diversity increases so trust/cooperation fall. We accept for the purpose of assessing this reason, that, whatever causes trust, the influence of diversity is such that trust falls as diversity rises. We focus instead on what cause of cooperation might explain why it falls as diversity increases. We do this because Ashraf and Galor (2013) offer, in effect, an argument along these lines by utilizing the traditional evolutionary explanation of 'altruism' (the motivational category used to explain cooperation in this literature): i.e. such 'altruism' arises from genetic relatedness. This is because, as Ashraf and Galor note, 'cooperation among genetically related individuals can indeed be collectively beneficial as it ultimately facilitates the propagation of shared genes to the next generation'(p.4). With this account, we should expect, like Ashraf and Galor, that 'altruism' (i.e. cooperation) to be weaker in more genetically diverse populations because individuals are on average less genetically related in such populations.

Against this traditional evolutionary account of the origins of altruism, however, there is a more recent evolutionary one: 'parochial altruism' (e.g. see Choi and Bowles, 2007). This holds that 'altruism' within any group of individuals arises on evolutionary grounds when groups are in conflict with each other. This is because individual survival in these circumstances depends on belonging to a group that can solve group public goods problems associated with winning such conflicts. ${ }^{3} \quad$ In so far as genetic diversity is more likely to be associated in evolutionary history with conflicts between groups (for which there is some evidence, see Arbatli et al, 2018), then genetic diversity will, on this account, be associated with higher average levels of cooperation within each group.

There is also another rather different, non-specific, evolutionary argument for why diversity might in practice promote cooperation. It is weaker and turns on accepting that trust is undermined by diversity and depends on noting that, despite this, we observe successful, in an evolutionary sense, diverse societies. For diverse societies to be successful, they must therefore have some compensating other elements of social capital to make good the deficiencies in trust. Of course, this need not be an ability to cooperate and this is why the argument is weaker. Nevertheless, an ability to cooperate is an obvious candidate in what is, in effect, a

\footnotetext{
${ }^{3}$ For some experimental evidence in support of this mechanism, see Ereve et al (1993).
} 
'necessity is the mother of invention' type argument for why diversity might have the reverse effect on cooperation.

Thus, again, although we would not wish to discount on theoretical grounds that trust and cooperation move in tandem in response to diversity on the basis of this third kind of connection, there is no clear reason to suppose they will. Hence, like the other theoretical considerations, this one points to the relation between diversity and trust and cooperation being a matter for empirical determination.

\section{EXISTING AND NOVEL EMPIRICAL EVIDENCE}

We present evidence in this section that addresses two problems in the empirical literature examining the relation between diversity and the social capital of trust and cooperation. The first problem is that a contemporary measure of diversity is often taken as an explanatory variable in a regression on a measure of trust (and sometimes also cooperation) when this measure of diversity is unlikely to be an exogenous variable. Rather the extent of diversity in a country or a region or city will itself be endogenous. This problem has been addressed in two recent studies that have used two deep, historical and so plausibly exogenous variables that might influence cultural beliefs around trust and cooperation: Ashraf and Galor (2013) use the genetic diversity of the population and Enke (2018) uses the tightness of the historical kinship systems in a given population.

Ashraf and Galor (2013) find in a cross-country study that genetic diversity has a negative effect on contemporary levels of trust across countries. They do not, however, present any evidence that genetic diversity also has a negative influence on cooperation. Our first empirical contribution is to follow their approach in addressing this gap by using genetic diversity as a possible explanatory exogenous variable affecting contemporary willingness to cooperate. We do this on cross country aggregate data like Ahsraf and Galor; and, in addition, we test for the influence of genetic diversity on trust and cooperation using individual level data. This first contribution is identified in the first row of the summary Table 1 on our empirical contributions below.

Enke (2019) uses historical kinship tightness (that might be connected to the origins of more or less diversity) to explain a range of contemporary moral values (largely based on the Moral Foundations taxonomy of such values). He does not directly test whether these moral values explain the social capital of trust and cooperation. Indeed, although the paper 
Table 1: Social CApital Regressions; A =Aggregate Data, I = Individual Data.

\begin{tabular}{|c|c|c|c|}
\cline { 2 - 4 } \multicolumn{1}{c|}{} & \multicolumn{3}{c|}{ Dependent variable } \\
\hline \hline \multirow{3}{*}{$\begin{array}{c}\text { Exogenous } \\
\text { variable }\end{array}$} & Trust & Cooperation \\
\cline { 2 - 4 } & Genetic diversity & A\&I & A\&I \\
\cline { 2 - 4 } & Kinship strength & A\&I & A\&I \\
\hline
\end{tabular}

is titled 'Kinship, cooperation and the evolution of moral systems', the assumption is that the character of moral values, so distinguished, contributes more or less to the social dilemmas involving trust and cooperation in practice. This may be so, but there is no direct test of the influence of historical kinship strength on contemporary levels of social capital in the form of willingness to trust and cooperate with others. Our second contribution effectively fills this gap and again involves not only aggregate cross country but also individual level data. It is picked up in second row of Table 1.

Thus we fill the diversity-cooperation gap in Ashraf and Galor and he explicit trust-diversity and cooperation-diversity gaps in Enke; and we use not only aggregate, cross-country data, we introduce individual level data for the first time. To put this slightly differently, Table 1 identifies 8 regressions that we run: 4 aggregate and 4 individual. Only one has been done before: the top left cell, A. The remaining seven are our contribution.

\section{Observational data on Trust and Cooperation}

The observational empirical work on the determinants of trust almost always uses a version of a survey question. We use the following.

\section{World Value Survey (WVS)}

"Generally speaking, would you say that most people can be trusted or that you need to be very careful in dealing with people?"

People are given the binary option for an answer: either "Most people can be trusted" or "Need to be very careful".

We use WVS when testing for 'trust' in the aggregate, cross-country data because the WVS was used by Ashraf and Galor in their study of the determinants of trust. In this way we replicate their work and extend their framework exactly when we use similar WVS measures of cooperation on the same group of countries with the same specification that has genetic 
diversity as the key explanatory variable. Since Enke does not have a measure of trust or cooperation, but does have a similar group of countries, we again use the WVS trust and cooperation measures for comparability when we test for the influence of kinship strength rather than genetic diversity.

The European Social Survey (ESS) asks a similar question but invites responses on a continuum from $10=$ "Most people can be trusted" to $0=$ "you can't be too careful".

We use ESS when we turn to the individual level regressions because ESS has data, that WVS does not, which allows us to test for the influence of genetic diversity and kinship strength at the individual level. We explain how this is done below.

The WVS questions that have been used to assess cooperation focus on free riding.

Subjects are asked to assess the justifiability of instances of free riding on a scale of 1 (= never justifiable) to 10 (= always justifiable). The less justifiable free riding is thought to be, the stronger the norm of cooperation.

- It is justifiable to avoid fares on public transport;

- It is justifiable to cheat on taxes if you have the chance;

- It is justifiable to claim government benefits to which you are not entitle

There are no similar questions on the ESS, but it has a question that refers to a possible ingredient in cooperation (that is the willingness to contribute to something that affects others). It asks: "It is important to help people and care for others well-being", and respondents answer on a 0-5 likert scale, with higher values corresponding to higher agreement.

\section{StUdying tRUST AND COOPERATION IN A SINGLE EMPIRICAL DESIGN}

We present our analysis country-level and individual-level analysis here. We only present here the main elements and findings. The Appendix describes in careful steps the data work, descriptive statistics, estimation details and robustness checks.

Country level. We begin by following Ashraf and Galor by estimating equation (1) on aggregate country data.

$$
y_{i}=\alpha+\beta G_{i}+\gamma_{\mathbf{1}}^{\prime} \ln \mathbf{X}_{\mathbf{i}}+\gamma_{\mathbf{2}}^{\prime} \ln \mathbf{Z}_{\mathbf{i}}+\gamma_{\mathbf{2}}^{\prime} \ln \mathbf{W}_{\mathbf{i}}+\mu_{i}
$$


The dependent variable $y_{i}$ is a survey aggregate measure of 'trust' or 'cooperation' in country $i$. We reverse code the WVS measure of free riding so that an increase reflects, like in the trust variable, an increase in the inclination towards cooperation (i.e. a stronger feeling against free riding).

The key explanatory variable $G$ is either a measure of genetic diversity or kinship strength in country $i$. The coefficient on this is what interests us and we report it below. In the aggregate equations, the measures of genetic diversity and kinship strength are taken from Ashraf and Galor and Enke respectively.

The remaining explanatory variables in (1) are controls: $X_{i}$ is a proxy for the Neolithic transition timing and land productivity controls for country $i$; $Z_{i}$ is a vector of institutional and cultural controls including ethnic fractionalization and the percentage of people at risk of contracting malaria, while $W_{i}$ is a vector of additional geographical controls including log absolute latitude, and the mean distance to accessible waterway.

The cooperation questions have not been asked for as many countries as the trust one for the waves of the WVS from 1981-2009 that were available to Ashraf and Galor. However, we are able to exploit the latest wave of the WVS and estimate the relation over 1981-2014 waves and this enables us to cover almost exactly the same set of countries as they did. We have 56 or 57 depending on the cooperation question as compared with the 58 countries that they covered in their trust equation.

Individual level. We are able to use individual level data to check on the influence of genetic diversity by focusing on second generation immigrants. For this purpose, we examine whether the genetic diversity of their parent's originating country predicts their children's trust and cooperation levels. The rationale for this is as follows.

Assuming that trust and cooperation attitudes are culturally transmitted, then the parent's cultural contribution to their children's beliefs will be captured by the attitudes that were prevalent in their originating countries. Again if genetic diversity in these originating countries is the key source of differences in these trust and cooperation norms that the parents inherited, then we expect the genetic diversity of the parents' countries first influences their parent's attitudes and then their children's attitudes to trust and cooperation. By focusing on individuals in this way, we not only have individual level evidence to complement the cross-country evidence, we also have much greater variation in the genetic diversity variable 
because we cover many more countries than in the country level data. Moreover, focusing on second generation immigrants helps to reduce the selection bias caused by their parents' decision to migrate. Controlling for country fixed effects, we isolate the ancestral from the social component of the effect of diversity on trust and cooperation. The virtue of the ESS over the WVS individual data is that it gives individual observations on the parents' country of origin for second generation immigrants and so allows us to conduct this additional individual level check.

We estimate the following equation:

$$
y_{i, g}=\alpha+\beta G_{i, g}+\gamma^{\prime} \mathbf{x}_{\mathbf{i}, \mathbf{g}}+\theta_{g}+\mu_{i, g}
$$

where $y_{i, g}$ is the score of each dependent variable individual $i$ in country-round $g$. The dependent variable ' $y$ ' is again either a measure of 'trust' or 'cooperation'.

In the above regression, $G_{i, g}$ is our key independent variable. It represents either the respondent's mother ancestry adjusted predicted level of genetic diversity or her kinship score. ${ }^{4}$ Furthermore, $\mathbf{x}_{\mathbf{i}, \mathbf{g}}$ is a vector of baseline individual covariates, $\theta_{g}$ is a country-year specific intercept and $\mu_{i, g}$ is the error term. The set of sociodemographic control variables include both the education attainment of the respondent (0 if no university diploma, 1 instead) and the education attainment of the respondents' parents (0 if no university diploma, 1 instead). We further control for a standard set of sociodemographic covariates including sex (0 for males, 1 for females), age $(15-99)$ and squared age, household size, the employment status (employed vs. unemployed) and the domicile (where 0 represents big city and 4 represents the rural countryside). Standard errors are clustered at country level.

Results. We plot the coefficient of main interest $G$ in Figure 1 and provide summary statistics, detailed regression tables and robustness checks in the Appendix. The panels mirror the cells in Table 1. The two subfigures in the top panel (1a) plot the effect of genetic diversity and kinship on trust and cooperation in the country-level analysis. In both cases, we observe a negative effect on trust and a positive effect on cooperation, though this empirical pattern is only significant in the former case. Further analysis in the Appendix shows that using alternative metrics for the dependent variables result in similar conclusions.

\footnotetext{
${ }^{4}$ Using father ancestry adjusted predicted level of genetic diversity instead yields the same results because the correlation between these two is expectedly high, $\rho=.94$.
} 
Figure 1: Diversity, TRUST AND COOPERATION.

(a) THE COUNTRY-LEVEL.

Genetic diversity

- Trust $=$ Cooperation

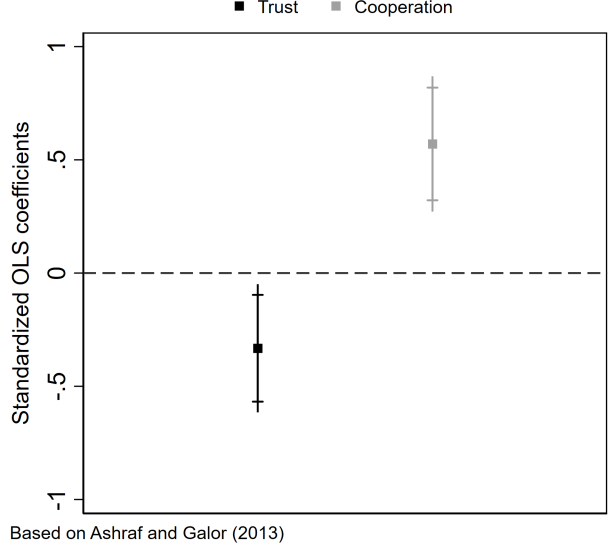

Kinship

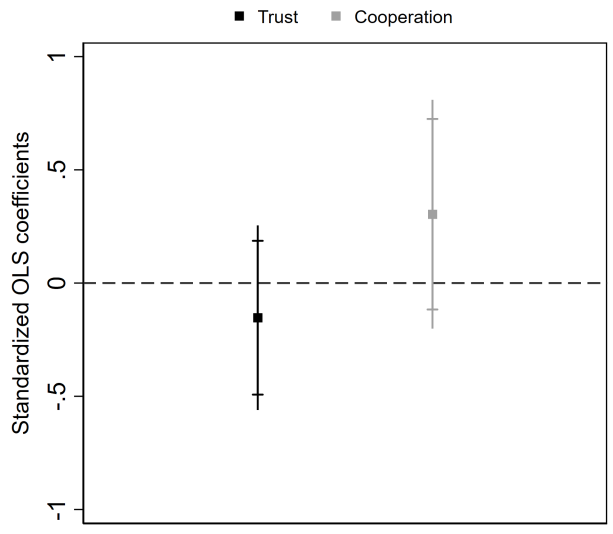

Based on Enke (2019)

(b) THE INDIVIDUAL-LEVEL.
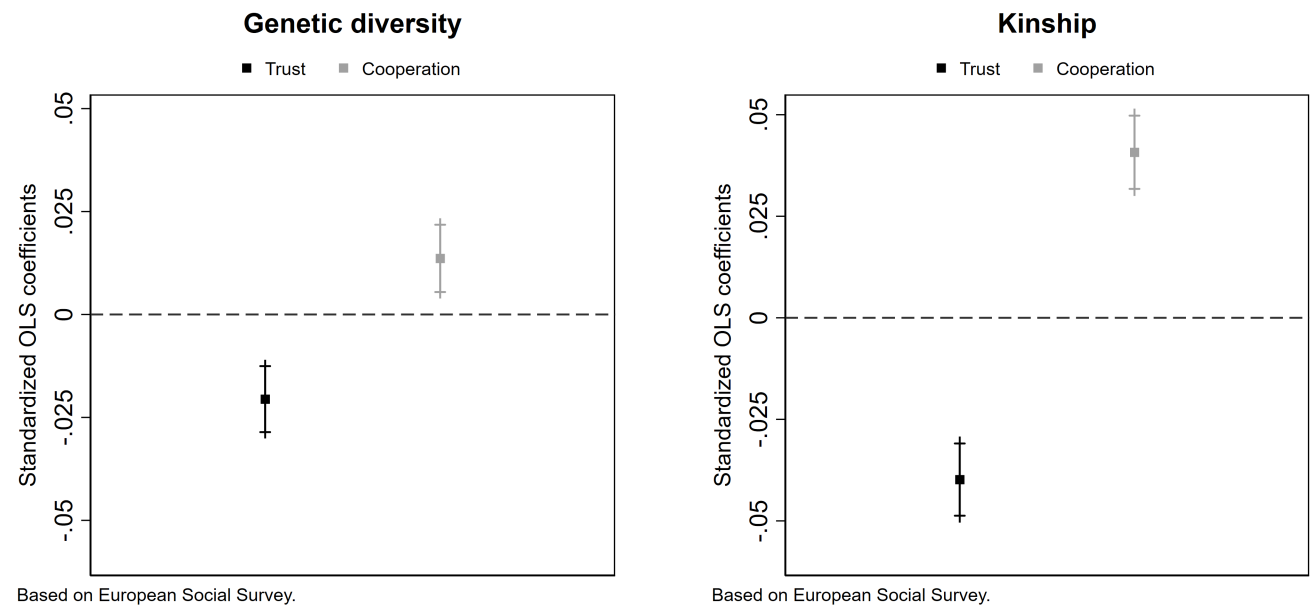

At the country-level, the reported coefficients are OLS estimates controlling for Neolithic transition timing, land productivity, ethnic fractionalization, the percentage of people at risk of contracting malaria, the log of the absolute latitude, and the mean distance to accessible waterway. At the individual-level, we report OLS coefficients controlling for education, age, gender, household composition, domicile type and we cluster standard error at the country-level. Details of both estimations are presented in appendix. 
Remarkably, using individual-level data under the assumption that diversity is transmitted within the household confirms the divergent effect of diversity- either measured as "genetic diversity" or "kinship strength" - on "trust" and "cooperation". Indeed, two subfigures in bottom panel (1b) demonstrate that these effects are sizable and significant. In this case, unlike for the country level analysis, the standardized OLS coefficients are larger when using kinship scores than genetic diversity as a main independent variable.

Although we have described the evidence linking contemporary trust negatively with diversity a part of the emerging conventional wisdom, there are studies that point in the opposite direction. ${ }^{5}$ Our evidence in this section, therefore, supports the conventional wisdom in this respect. Where we depart from the conventional wisdom is in the conclusion that, if anything, diversity promotes cooperation.

\section{EXPERIMENTAL EVIDENCE ON HOW DIVERSITY AFFECTS TRUST AND COOPERATION}

Our second source of causal evidence comes from laboratory experiments on trust and cooperation. The decision problem to elicit trust that is used in laboratory experiments is the so-called Trust Game. ${ }^{6}$ This is a two person sequential game, as follows.

1st mover has an endowment $(\mathrm{X})$ and must decide how much $(\mathrm{Y})$ to 'give' to the 2 nd mover in the knowledge that it will be multiplied by 3 and the 2 nd mover will then decide how much (of $3 \mathrm{Y}$ ) to 'return' to the 1st mover

2nd mover decides how much of what they have received (3Y) to 'return' to the 1st mover.

A selfish 1st mover anticipating a selfish 2nd mover will 'give' nothing because they expect that whatever is given and multiplied will be kept by a selfish 2nd mover. The game gets its name as result because, as it were, 'if only the 1st mover could 'trust' that the 2nd mover will prove 'trustworthy and 'return' an appropriate amount, then they can both benefit from the

\footnotetext{
${ }^{5}$ On the conventional wisdom side, for example, there is the influential study by Alesina and La Ferrara (1999) shows that net of socioeconomic factors, ethnic fractionalization reduces interpersonal trust in the U.S (1999). These findings were reinforced in the same context yet with different data and approaches by Putnam (2007), and generalized to Canada according to Stolle, Soroka and Johnston (2008). Against this 'wisdom', there is most notably, combining micration data with individual-level data on attitudes, Hooghe et al (2009) who document a positive relationship between ethnic diversity and trust in Europe. Similarly, Abascal and Baldassarri (2015) reassess the evidence put forth by Putnam (2007), arguing that Putnam's finding is due to residential sorting: nonwhites report lower trust and are overrepresented in heterogeneous communities. Also see Sturgis et al (2011), Lolle and Torpe (2011) and Andersen and Paskeviciute (2006).

${ }^{6}$ See Berg, Dickhaut and McCabe (1995).
} 
multiplying factor'. The proportion 'given' by the 1st mover is used as an index of 'trust' and the proportion returned by the 2nd mover is taken to be an index of their 'trustworthiness'.

In game theory and laboratory experiments, 'cooperation' is typically the label used to identify the alternative strategy to 'defection' in the Prisoner's dilemma (PD) game. Wikipedia, for example, has this opening sentence for its entry on the dilemma:

'The prisoner's dilemma is a standard example of a game analysed in game theory that shows why two completely rational individuals might not cooperate (emphasis added), even if it appears that it is in their best interests to do so'.

Thereafter, the two strategies are labeled, tellingly, in the various illustrations given by Wikipedia as 'cooperate' and 'defect'. Likewise, in the n-person PD, the Public Goods Game (PG), contributing to the public good is referred to as 'cooperating'. The PG is not only a $n$-person version of the PD, it also typically allows individuals a continuum of choices over how much to contribute to the public good and not a binary choice between contributing everything or nothing.

What makes the $\mathrm{PD} / \mathrm{PG}$ interesting is that mutual cooperation/maximum contribution is better for all than mutual defection/zero contribution. The difficulty, however, in sustaining the Pareto superior mutual cooperation outcome in these games is that an individual will always secure higher pay-offs for themselves by contributing nothing whatever the others contribute: that is, there is an incentive to free ride on what others contribute and when everyone does this the inferior mutual defection/zero contribution outcome results.

In what follows we report on two experiments that examine how diversity affects behaviour in these two games (see Hargreaves Heap and Zizzo, 2009 and Corr et al, 2015). They have been chosen because they use the same method for generating diversity and the version of each game involves two players. So, the only substantive difference across the two experiments is the decision problem: the one tests for the ability to trust and the other, the ability to overcome the free rider problem and secure cooperation. In particular, in both experiments there is a control or baseline where subjects play either a 2-person trust game or a 2-person public goods game. It is called a 2-person public goods game because each individual can choose along a continuum of how much to contribute to the public good from an individual endowment (and not just between all or nothing). In the baseline in both experiments, the subjects are randomly and anonymously matched with other subjects from that experimental session. The subjects are told the result of each game each time after it has been played. 
Table 2: Trust game giving RAtes And PG CONTRibution Rates

\begin{tabular}{|c|c|c|c|}
\cline { 2 - 4 } \multicolumn{1}{c|}{} & Baseline & To own group & To other group \\
\hline \hline Giving rate & 0.56 & 0.52 & 0.35 \\
\hline Contribution rate & 0.26 & 0.40 & 0.26 \\
\hline
\end{tabular}

The key to testing for the influence of diversity comes from the contrast with the group treatments in both experiments. In the group treatments, the subjects are randomly assigned at the beginning of the experiment either to the 'red' group or the 'blue' group. So, there are no differences across the experiments in the way group identification arises. They are artificial groups, they are induced in the same minimal way and given the same labels. Subjects are then randomly assigned to play that experiment's game with someone from that experimental session subject to the condition that they sometimes play with someone from their own group and they sometimes play with someone from the other group. In these group treatments, the subjects know each other's group identity as well as their own (i.e. group identity is common knowledge); and they not only receive information on the result of the game after it has been played (as in the control/baseline), they also receive updated information on the average behaviour of Red and Blue group members in own and between group interactions. Thus, for each decision problem/game, we observe how subjects behave when there are no group identifications in the baseline (i.e. the population is homogenous in this respect) and we observe how another set of subjects behave when they belong to one of two groups and interact both with own and other group members (i.e. the population is heterogenous or diverse in its group identifications). The differences in behaviour for each game between baseline and group identity treatments, therefore, reveals the effect of diversity versus homogeneity, in this sense of group identifications among the population, on behaviour in each game.

Table 2 gives the results for the average giving rate and the average contribution rate in the Baseline in the group treatments, where we distinguish in the latter between own and other group rates. The first row gives the 'giving' rate for the trust game. The 'giving' rate to 'own group' members is not significantly different from the rate in the baseline when there are no groups, but both are significantly higher than the 'giving' rate to 'other group' members in the diverse population setting. Thus, the introduction of group differentiation to create a diverse population does causally lower trust in the lab whenever there are interactions between members of the different groups (as compared with the trust in an homogeneous population that has no such group identities). 
The $2^{\text {nd }}$ row in Table 2 gives the analogous results for the contribution rates in the PG. This time there is no difference between the contribution rates in the homogeneous population and in the diverse population when the interaction takes place between members of different groups. But the contribution rate among own group members in the diverse population is higher than both these contribution rates. Thus, the introduction of group differentiation to create a diverse population does causally increases cooperation in the lab whenever there are interactions between members of the same group (again, as compared with the level of cooperation in homogeneous populations with no such group identities).

Although this comparison is particularly appropriate (for our purpose of comparing the effect of diversity on trust and cooperation) because both experiments share an experimental set up, the result for PG has been noticed before in other contexts. ${ }^{7}$ Indeed a recent metasurvey remarks that "we find support for the hypothesis that intergroup discrimination in cooperation is the result of ingroup favoritism rather than outgroup derogation' 8 The contrast in the Trust Game experiment, to use these terms, is that discrimination (the in-group bias) came from outgroup derogation not ingroup favoritism. In other words, the exact opposite to that in the PG. ${ }^{9}$

These experimental results therefore cohere with those we have reported from the observational data using the deep historical and exogenous measures of diversity. Together they suggest that diversity impairs trust but, if anything, improves cooperation.

\section{Conclusion}

Does diversity threaten cooperation? Extant empirical research gives overall a positive answer to this question. That diversity and cooperation can not coexist has a major consequence: it leads to frame two cornerstone of liberal societies - freedom of movement and the welfare state - as competing objectives. We argue and show that such a policy dilemma may not exist. While diversity does seem to erode trust, if anything, the ability to overcome the free-rider problem and so cooperate with one another rises in diverse societies.

The burden of our argument comes from the new empirical evidence that we present on the

\footnotetext{
${ }^{7}$ E.g. see Buchan et al (2009) for a similar result in a different setting.

${ }^{8}$ See Bailliet et al (2014).

${ }^{9}$ It is perhaps worth noting that there is some experimental evidence outside of the context of diversity examining whether trust helps predict cooperation. The evidence tends to be mixed, see, for instance, the meta-analysis by Bailliet and van Lange (2013).
} 
influence of diversity on trust and cooperation. This is because we have argued that there is no theoretical reason, although trust is often thought to move in tandem with cooperation, for the two to be fundamentally linked in this way. It is for this reason an empirical question. Our empirical evidence is also new. It addresses the problem of identifying the causal influence of diversity in two ways. One is through the use of deep historical, and so plausibly exogenous, indicators of diversity. They have hitherto been used to plot the influence of diversity on trust, but we are the first to extend this analysis to cooperation. We further extend this analysis to individual level data on both trust and cooperation. The other is through the use of laboratory experiments to examine the causal relation between diversity and trust and cooperation. Both types of causal evidence point to the differing effects of diversity on the two key components of social capital: trust and cooperation.

Some caveats are in order. For first, while we theorize and demonstrate that interpersonal trust is not a necessary condition for cooperation, we are not in a position to fully characterize the mechanism through which this happens. Moreover, abstracting from how institutions and norms moderate the mapping between diversity and cooperation bind the policy relevance of our argument. We nevertheless hope to provide useful insights to the interdisciplinary literature on diversity and cooperation. Our paper questions the extent to which framing public opposition to diversity as "rational" on the ground that the latter ultimately decreases cooperation. It also highlights the conceptual flaws behind the documented conflation of trust with cooperation in empirical studies. Finally, our findings speak to the debate about competing theories of human cooperation, backing parochial altruism over traditional evolutionary accounts. 


\section{REFERENCES}

[1] Abascal, Maria, and Delia Baldassarri. 2015. "Love thy neighbor? Ethnoracial diversity and trust reexamined." American Journal of Sociology 121(3): 722-782.

[2] Alesina, Alberto, and Eliana La Ferrara. 2002. "Who trusts others?" Journal of Public Economics 85 (2): 207-234.

[3] Alesina, Alberto, and Eliana La Ferrara. 2005. "Ethnic diversity and economic performance". Journal of Economic Literature 43(3): 762-800.

[4] Anderson, Christopher J., and Aida Paskeviciute. 2006. "How ethnic and linguistic heterogeneity influence the prospects for civil society: A comparative study of citizenship behavior." The Journal of Politics 68(4): 783-802.

[5] Arbatli, Cemal Eren, Quamrul Ashraf, Oded Galor and Marc Klemp. 2018. "Diversity and conflict". Available at SSRN 3138492.

[6] Ashraf, Quamrul, and Oded Galor. 2013. "The'Out of Africa'hypothesis, human genetic diversity, and comparative economic development". American Economic Review 103 (1): $1-46$.

[7] Bailiet, David and Paul Van Lange. 2014 "Trust, conflict and cooperation: a metaanalysis", Psychological Bulletin 139(50): 1090-1112.

[8] Bailliet, David, Carsten De Dreu and Junhui Wu. 2014. "Ingroup favoritism in cooperation: a meta-analysis" Psychological Bulletin 140(6): 1556-1581.

[9] Banting, Keith. G. and Will Kymlicka, Eds. 2006. Multiculturalism and the Welfare State: Recognition and Redistribution in Contemporary Democracies. Oxford, Oxford University Press.

[10] Barry, Brian. 1965. Political Argument. London: Routledge and Kegan Paul.

[11] Barry, Brian. 2001. Culture and Equality: and egalitarian critique of multiculturalism. Cambridge: Polity Press.

[12] Berg, Joyce, John W. Dickhaut, and Kevin A. McCabe. 1995. "Trust, Reciprocity, and Social History." Games and Economic Behavior 10(1): 122-142. 
[13] Buchan, Nancy, Gianluca Grimalda, Rick Wilson, Marilyn Brewer, Enrique Fatas and Margaret Foddy. 2009. "Globalization and human cooperation", Proceedings of National Academy of Sciences 106(11), 4138-4142.]

[14] Carlin, Ryan E., and Gregory J. Love. 2013. "The politics of interpersonal trust and reciprocity: An experimental approach" Political Behavior 35(1): 43-63.

[15] Carlin, Ryan E., and Gregory J. Love. 2018. "Political competition, partisanship and interpersonal trust in electoral democracies." British Journal of Political Science 4(1): 115.

[16] Choi, Jung-Kyoo, and Samuel Bowles. 2007. "The coevolution of parochial altruism and war". Science 318 (5850): 636-640.

[17] Corr, Philip J., Shaun P. Hargreaves Heap, Charles R. Seger, and Kei Tsutsui. 2015. "An experiment on individual parochial altruism revealing no connection between individual altruism and individual parochialism". Frontiers in Psychology 6:1261.

[18] Enke, Benjamin. 2019. "Kinship, Cooperation, and the Evolution of Moral Systems" Quarterly Journal of Economics 134(2): 953-1019.

[19] Erev, Ido, Gary Bornstein, and Rachely Galili. 1993. "Constructive intergroup competition as a solution to the free rider problem: A field experiment". Journal of Experimental Social Psychology 29 (6): 463-478.

[20] Falk, Armin, Anke Becker, Thomas Dohmen, Benjamin Enke, David Huffman and Uwe Sunde. 2018. "Global evidence on economic preferences". The Quarterly Journal of Economics 133 (4): 1645-1692.

[21] Fischbacher Uri and Simon Gachter. 2006. "Heterogeenous social preferences and the dynamics of free riding" IZA Discussion Paper No. 2011.

[22] Gilligan, Michael J., Benjamin J. Pasquale, and Cyrus Samii. 2013. "Civil war and social cohesion: Lab-in-the-field evidence from Nepal." American Journal of Political Science 58(3): 604-619.

[23] Gintis, Herbert. 2016. "A typology of human morality" in David S. Wilson and Alan Kirman (eds) Complexity and Evolution. Cambridge: MIT Press. 
[24] Goodhart, David. 2013. The British Dream: Successes and failures of post-war immigration. Atlantic Books Ltd.

[25] Hargreaves Heap, Shaun P., and Daniel J. Zizzo. 2009. "The value of groups". American Economic Review 99 (1): 295-323.

[26] Hooghe, Marc, et al. 2009. "Ethnic diversity and generalized trust in Europe: A crossnational multilevel study." Comparative political studies 42(2): 198-223.

[27] Hobbes, Thomas. 1651. Leviathan. St Paul's Churchyard: Andrew Crooke at the Green Dragon.

[28] Hume, David. 1738, A Treatise of Human Nature. Harper Torch edition.

[29] Jamal, Amaney, and Irfan Nooruddin. 2010. "The democratic utility of trust: A crossnational analysis." The Journal of Politics 72(1): 45-59.

[30] Kaufmann, Eric. 2018. Whiteshift: Populism, Immigration and the Future of White Majorities. Penguin UK.

[31] Keele, Luke. 2007. "Social capital and the dynamics of trust in government" American Journal of Political Science 51(2): 241-254.

[32] Knack, Stephen, and Philip Keefer. 1997. "Does social capital have an economic payoff? A cross-country investigation". The Quarterly Journal of Economics 112 (4): 1251-1288.

[33] Lane, Tom. 2015. "Discrimination in the laboratory: a meta-analysis of economic experiments" European Economic Review 90: 375-402.

[34] Levi, Margaret. 1996. A state of trust.

[35] Lolle, Henrik, and Lars Torpe. 2011. "Growing ethnic diversity and social trust in European societies." Comparative European Politics 9(2): 191-216.

[36] Mehta, Judith, Chris Starmer and Robert Sugden. 1994. "The nature of salience: an experimental investigation of pure coordination games", American Economic Review 84(3): 658-673.

[37] Nannestad, Peter. 2008. "What have we learned about generalized trust, if anything?" Annual Review of Political Science 11: 413-436. 
[38] Pundestone, William. 1993. Prisoner's Dilemma. New York: Anchor books.

[39] Putnam, Robert. 2000. Bowling alone. The collapse and revival of American community. New York: Simon \& Schuster.

[40] Putnam, Robert. 2007. "E pluribus unum: diversity and community in the twenty first century" Scandinavian Journal of Political Science 30(2), 137-174.

[41] Rawls, John. 1971. A Theory of Justice. Cambridge: Harvard University Press.

[42] Schelling, Thomas. 1960. Strategy of Conflict. Cambridge: Harvard University Press.

[43] Stolle, Dietlind, Stuart Soroka, and Richard Johnston. 2008. "When does diversity erode trust? Neighborhood diversity, interpersonal trust and the mediating effect of social interactions." Political studies 56(1): 57-75.

[44] Sturgis, Patrick, et al. 2011. "Does Ethnic Diversity Erode Trust? Putnam's' Hunkering Down' Thesis Reconsidered." British journal of political science 57-82.

[45] Taylor-Goodby, Peter. 2005. Ideas and Welfare State Reform in Western Europe. London: Palgrave. 


\section{Online Appendix}

\section{A Descriptive statistics}

- Table 3 provides summary statistics relative to the country-level analysis.

- Table 4 provides summary statistics relative to the individual-level analysis for the first four rounds of the ESS.

- Table 5 provides summary statistics relative to the individual-level analysis for the last three rounds of the ESS. 
Table 3: Summary STATISTICS For COUnTRY-LEVEl ANALYSis.

\begin{tabular}{lccccccccccc}
\hline & \multicolumn{3}{c}{ Americas } & \multicolumn{3}{c}{ Asia } & \multicolumn{2}{c}{ Europe } & \multicolumn{2}{c}{ Oceania } & \multicolumn{2}{c}{ Sub-S. Africa } \\
& mean & sd & mean & sd & mean & sd & mean & sd & mean & sd \\
\hline $\begin{array}{l}\text { Dependent variables } \\
\text { Trust }\end{array}$ & 0.18 & 0.10 & 0.29 & 0.13 & 0.31 & 0.14 & 0.49 & 0.03 & 0.14 & 0.06 \\
Cooperation & -0.36 & 2.06 & 0.23 & 1.41 & -0.20 & 1.45 & 1.06 & 0.04 & 0.23 & 1.43 \\
Independent variables & & & & & & & & & & \\
Genetic diversity & 0.70 & 0.03 & 0.72 & 0.02 & 0.73 & 0.01 & 0.69 & 0.03 & 0.75 & 0.01 \\
Kinship tightness & 0.50 & 0.35 & 0.68 & 0.24 & 0.32 & 0.30 & 0.59 & 0.31 & 0.88 & 0.11 \\
log Neolithic transition timing & 8.56 & 0.20 & 8.85 & 0.26 & 8.74 & 0.22 & 8.50 & 0.19 & 7.95 & 0.35 \\
log arable land & 2.00 & 1.01 & 2.03 & 1.29 & 2.86 & 1.21 & 1.25 & 1.37 & 1.98 & 1.12 \\
log absolute latitude & 2.73 & 0.68 & 3.06 & 0.82 & 3.89 & 0.15 & 2.49 & 0.75 & 2.13 & 1.00 \\
Ethnic fractionalization & 0.42 & 0.21 & 0.42 & 0.22 & 0.30 & 0.21 & 0.24 & 0.22 & 0.66 & 0.23 \\
Social infrastructure & 0.46 & 0.21 & 0.50 & 0.26 & 0.77 & 0.19 & 0.56 & 0.21 & 0.30 & 0.13 \\
Risk of contracting malaria & 0.09 & 0.21 & 0.21 & 0.32 & 0.00 & 0.00 & 0.20 & 0.34 & 0.85 & 0.30 \\
Terrain roughness & 0.22 & 0.15 & 0.24 & 0.16 & 0.18 & 0.13 & 0.34 & 0.19 & 0.19 & 0.27 \\
Population in tropical zones & 0.63 & 0.40 & 0.22 & 0.38 & 0.00 & 0.00 & 0.27 & 0.40 & 0.50 & 0.42 \\
Mean distance to waterway & 0.26 & 0.47 & 0.45 & 0.59 & 0.14 & 0.38 & 0.16 & 0.17 & 0.50 & 0.38 \\
\hline
\end{tabular}

Notes. Data can be downloaded from the replication material provided by Ashraf and Galor as well as Falk et al. 
Table 4: Summary STATISTICS FOR INDIVIDUAL-LEVEL ANALYSIS.

\begin{tabular}{lcccccccc}
\hline & \multicolumn{2}{c}{$\mathbf{2 0 0 4}$} & \multicolumn{2}{c}{$\mathbf{2 0 0 6}$} & \multicolumn{2}{c}{$\mathbf{2 0 0 8}$} & \multicolumn{2}{c}{$\mathbf{2 0 1 0}$} \\
& mean & sd & mean & sd & mean & sd & mean & sd \\
\hline $\begin{array}{l}\text { Dependent variables } \\
\text { Trust }\end{array}$ & 4.95 & 2.47 & 5.06 & 2.47 & 4.89 & 2.46 & 4.89 & 2.44 \\
Cooperation & 2.69 & 1.04 & 2.70 & 1.00 & 2.80 & 1.02 & 2.90 & 1.01 \\
Independent variables & & & & & & & & \\
Genetic diversity (mother) & 0.73 & 0.01 & 0.73 & 0.01 & 0.73 & 0.01 & 0.73 & 0.01 \\
Kinship score (mother) & 0.33 & 0.27 & 0.32 & 0.28 & 0.38 & 0.30 & 0.41 & 0.31 \\
Female & 1.54 & 0.50 & 1.55 & 0.50 & 1.55 & 0.50 & 1.55 & 0.50 \\
Age of respondent & 44.71 & 17.77 & 45.27 & 17.52 & 45.65 & 17.62 & 45.46 & 17.89 \\
Size of household & 2.85 & 1.49 & 2.78 & 1.44 & 2.76 & 1.46 & 2.78 & 1.44 \\
Rural & 0.59 & 0.49 & 0.59 & 0.49 & 0.59 & 0.49 & 0.58 & 0.49 \\
University diploma & 0.27 & 0.44 & 0.33 & 0.47 & 0.30 & 0.46 & 0.22 & 0.42 \\
Mother has university diploma & 0.11 & 0.31 & 0.14 & 0.35 & 0.13 & 0.34 & 0.10 & 0.30 \\
Father has university diploma & 0.17 & 0.37 & 0.19 & 0.39 & 0.18 & 0.38 & 0.14 & 0.34 \\
Subjective income & 2.18 & 0.94 & 2.11 & 0.90 & 2.18 & 0.91 & 2.24 & 0.94 \\
Unemployed & 0.05 & 0.23 & 0.04 & 0.21 & 0.06 & 0.24 & 0.08 & 0.27 \\
\hline
\end{tabular}

Notes. Data can be downloaded from the European Social Survey. They are merged with those that from the replication material provided by Ashraf and Galor as well as Falk et al. 
Table 5: Summary Statistics For Individual-Level ANALysis.

\begin{tabular}{lcccccc}
\hline & \multicolumn{2}{c}{$\mathbf{2 0 1 2}$} & \multicolumn{2}{c}{$\mathbf{2 0 1 4}$} & \multicolumn{2}{c}{$\mathbf{2 0 1 6}$} \\
& mean & sd & mean & sd & mean & sd \\
\hline $\begin{array}{l}\text { Dependent variables } \\
\text { Trust }\end{array}$ & 5.05 & 2.39 & 5.14 & 2.32 & 5.32 & 2.31 \\
Cooperation & 2.89 & 0.98 & 2.87 & 1.00 & 2.92 & 0.95 \\
Independent variables & & & & & & \\
Genetic diversity (mother) & 0.73 & 0.01 & 0.73 & 0.01 & 0.73 & 0.01 \\
Kinship score (mother) & 0.37 & 0.29 & 0.37 & 0.30 & 0.38 & 0.31 \\
Female & 1.55 & 0.50 & 1.54 & 0.50 & 1.52 & 0.50 \\
Age of respondent & 45.98 & 17.84 & 46.19 & 17.69 & 46.29 & 17.60 \\
Size of household & 2.80 & 1.46 & 2.76 & 1.43 & 2.70 & 1.42 \\
Rural & 0.57 & 0.50 & 0.57 & 0.50 & 0.61 & 0.49 \\
University diploma & 0.25 & 0.43 & 0.25 & 0.43 & 0.27 & 0.44 \\
Mother has university diploma & 0.11 & 0.31 & 0.12 & 0.32 & 0.12 & 0.32 \\
Father has university diploma & 0.15 & 0.36 & 0.15 & 0.36 & 0.16 & 0.37 \\
Subjective income & 2.21 & 0.94 & 2.04 & 0.87 & 1.91 & 0.83 \\
Unemployed & 0.08 & 0.26 & 0.06 & 0.24 & 0.05 & 0.22 \\
\hline
\end{tabular}

Notes. Data can be downloaded from the European Social Survey. They are merged with those that from the replication material provided by Ashraf and Galor as well as Falk et al. 


\section{B FurThER ANALYSIS}

- Table 6 reports coefficients relative to the country-level analysis summarized in subfigure 1a of Figure 1.

- Table 7 details that using each form of cooperation separately, one consistently obtains a positive effect of diversity on cooperation.

- Table 8 replicates the robustness check presented by Ashraf and Galor (2013) in the second column of their Table 9. It adds years of schooling as a control variable. The coefficients of interest display minor changes but ancestry adjusted predicted genetic diversity still has a significant negative effect on interpersonal trust and a significant positive effect on cooperation.

- Table 9 reports coefficients from a specification that mimics Table 6 but imports data on their measure of trust and varieties of proxies for cooperation from Falk et al. (2018). Their data is summarized in their Table 1 and largely discussed in their online appendix. We then replicate the main regression using these proxies for trust, altruism, negative and positive reciprocity from Falk et al. (2018) with the same control variables as in Ashraf and Galor (2013). In this way, we check whether the results are sensitive to the choice of dependent variables for trust and cooperation. Unfortunately, this merging of the datasets reduces the sample to 45 countries rather than the original 58 . Table 4 shows that ancestry adjusted predicted genetic diversity has a negative but non-significant effect on interpersonal trust and a positive but also non-significant effect on each item related with cooperation. Therefore the coefficients for genetic diversity still have opposite signs in the trust and cooperation equations but none are significant. It is possible that the absence of significance is a product of the decrease in sample size. Nevertheless, we can reject the hypothesis that the sign on genetic diversity in any of the cooperation equations is negative.

- Table 10 reports coefficients relative to the individual-level analysis summarized in subfigure $1 b$ of Figure 1. 
Table 6: Genetic Diversity and kinship on Trust and Cooperation

\begin{tabular}{|c|c|c|c|c|}
\hline & \multicolumn{2}{|c|}{ Trust } & \multicolumn{2}{|c|}{ Cooperation } \\
\hline $\begin{array}{l}\text { Predicted } \\
\text { diversity (ancestry adjusted) }\end{array}$ & $\begin{array}{c}-1.729^{* *} \\
(0.728)\end{array}$ & & $\begin{array}{l}32.438^{* * *} \\
(8.390)\end{array}$ & \\
\hline $\begin{array}{l}\text { Kinship } \\
\text { score }\end{array}$ & & $\begin{array}{l}-0.064 \\
(0.084)\end{array}$ & & $\begin{array}{c}1.388 \\
(1.138)\end{array}$ \\
\hline $\begin{array}{l}\text { log Neolithic transition timing } \\
\text { (ancestry adjusted) }\end{array}$ & $\begin{array}{c}0.058 \\
(0.063)\end{array}$ & $\begin{array}{l}-0.029 \\
(0.058)\end{array}$ & $\begin{array}{l}-0.331 \\
(0.827)\end{array}$ & $\begin{array}{c}1.300 \\
(0.873)\end{array}$ \\
\hline $\begin{array}{l}\text { log percentage } \\
\text { of arable land }\end{array}$ & $\begin{array}{c}0.013 \\
(0.018)\end{array}$ & $\begin{array}{c}0.012 \\
(0.018)\end{array}$ & $\begin{array}{c}0.066 \\
(0.172)\end{array}$ & $\begin{array}{c}0.100 \\
(0.224)\end{array}$ \\
\hline log absolute latitude & $\begin{array}{l}-0.012 \\
(0.030)\end{array}$ & $\begin{array}{c}0.002 \\
(0.028)\end{array}$ & $\begin{array}{c}0.057 \\
(0.601)\end{array}$ & $\begin{array}{l}-0.170 \\
(0.643)\end{array}$ \\
\hline $\begin{array}{l}\text { Ethnic } \\
\text { fractionalization }\end{array}$ & $\begin{array}{c}0.040 \\
(0.067)\end{array}$ & $\begin{array}{c}0.022 \\
(0.068)\end{array}$ & $\begin{array}{l}-1.154 \\
(0.861)\end{array}$ & $\begin{array}{l}-0.829 \\
(0.957)\end{array}$ \\
\hline $\begin{array}{l}\text { Social } \\
\text { infrastructure }\end{array}$ & $\begin{array}{l}0.187^{* *} \\
(0.076)\end{array}$ & $\begin{array}{c}0.163 \\
(0.102)\end{array}$ & $\begin{array}{c}0.605 \\
(1.017)\end{array}$ & $\begin{array}{c}1.085 \\
(1.192)\end{array}$ \\
\hline $\begin{array}{l}\text { Percentage of population at risk } \\
\text { of contracting malaria }\end{array}$ & $\begin{array}{l}-0.074 \\
(0.079)\end{array}$ & $\begin{array}{l}-0.038 \\
(0.087)\end{array}$ & $\begin{array}{c}0.539 \\
(1.369)\end{array}$ & $\begin{array}{l}-0.066 \\
(1.391)\end{array}$ \\
\hline $\begin{array}{l}\text { Mean distance to } \\
\text { nearest waterway }\end{array}$ & $\begin{array}{l}-0.078 \\
(0.053)\end{array}$ & $\begin{array}{l}-0.056 \\
(0.053)\end{array}$ & $\begin{array}{c}0.393 \\
(1.318)\end{array}$ & $\begin{array}{c}0.051 \\
(1.390)\end{array}$ \\
\hline Constant & $\begin{array}{c}0.908 \\
(0.603)\end{array}$ & $\begin{array}{c}0.374 \\
(0.517)\end{array}$ & $\begin{array}{l}-20.962^{* *} \\
(7.995)\end{array}$ & $\begin{array}{r}-11.305 \\
(8.072)\end{array}$ \\
\hline$N$ & 58 & 58 & 56 & 56 \\
\hline
\end{tabular}

Notes. ${ }^{*} p<.10,{ }^{* *} p<.05,{ }^{* * *} p<.01$. As in Ashraf and Galor (2013), all regressions include geographical controls for terrain characteristics as well as OPEC, legal origin, Sub-Saharan Africa, and continent fixed effects. Heteroskedasticity-robust standard errors are reported in parentheses. 
Table 7: Genetic Diversity on Trust and Cooperation

\begin{tabular}{|c|c|c|c|c|}
\hline & \multirow[t]{2}{*}{ Trust } & \multicolumn{3}{|c|}{ Cooperation } \\
\hline & & Taxes & Benefits & $\begin{array}{l}\text { Public } \\
\text { Transport }\end{array}$ \\
\hline $\begin{array}{l}\text { Predicted diversity } \\
\text { (ancestry adjusted) }\end{array}$ & $\begin{array}{l}-1.729^{* *} \\
(0.728)\end{array}$ & $\begin{array}{l}8.674^{* *} \\
(3.718)\end{array}$ & $\begin{array}{l}18.190^{* * *} \\
(4.251)\end{array}$ & $\begin{array}{l}16.190^{* * *} \\
(4.105)\end{array}$ \\
\hline $\begin{array}{l}\text { log Neolithic transition } \\
\text { timing (ancestry adjusted) }\end{array}$ & $\begin{array}{c}0.058 \\
(0.063)\end{array}$ & $\begin{array}{c}0.198 \\
(0.415)\end{array}$ & $\begin{array}{l}-0.372 \\
(0.345)\end{array}$ & $\begin{array}{l}-0.307 \\
(0.377)\end{array}$ \\
\hline $\begin{array}{l}\text { log percentage of } \\
\text { arable land }\end{array}$ & $\begin{array}{c}0.013 \\
(0.018)\end{array}$ & $\begin{array}{l}-0.015 \\
(0.091)\end{array}$ & $\begin{array}{c}0.053 \\
(0.100)\end{array}$ & $\begin{array}{c}0.055 \\
(0.082)\end{array}$ \\
\hline log absolute latitude & $\begin{array}{l}-0.012 \\
(0.030)\end{array}$ & $\begin{array}{c}0.246 \\
(0.314)\end{array}$ & $\begin{array}{l}-0.256 \\
(0.260)\end{array}$ & $\begin{array}{c}0.028 \\
(0.259)\end{array}$ \\
\hline Social infrastructure & $\begin{array}{l}0.187^{* *} \\
(0.076)\end{array}$ & $\begin{array}{c}0.253 \\
(0.435)\end{array}$ & $\begin{array}{c}0.161 \\
(0.547)\end{array}$ & $\begin{array}{c}0.353 \\
(0.455)\end{array}$ \\
\hline Ethnic fractionalization & $\begin{array}{c}0.040 \\
(0.067)\end{array}$ & $\begin{array}{l}-0.757^{*} \\
(0.405)\end{array}$ & $\begin{array}{l}-0.204 \\
(0.425)\end{array}$ & $\begin{array}{l}-0.479 \\
(0.411)\end{array}$ \\
\hline $\begin{array}{l}\text { Percentage of population at } \\
\text { risk of contracting malaria }\end{array}$ & $\begin{array}{l}-0.074 \\
(0.079)\end{array}$ & $\begin{array}{c}0.672 \\
(0.687)\end{array}$ & $\begin{array}{l}-0.370 \\
(0.610)\end{array}$ & $\begin{array}{c}0.271 \\
(0.560)\end{array}$ \\
\hline $\begin{array}{l}\text { Mean distance to } \\
\text { nearest waterway }\end{array}$ & $\begin{array}{l}-0.078 \\
(0.053)\end{array}$ & $\begin{array}{c}0.346 \\
(0.511)\end{array}$ & $\begin{array}{c}0.086 \\
(0.597)\end{array}$ & $\begin{array}{c}0.065 \\
(0.592)\end{array}$ \\
\hline Constant & $\begin{array}{c}0.908 \\
(0.603)\end{array}$ & $\begin{array}{c}0.176 \\
(3.913)\end{array}$ & $\begin{array}{l}-1.004 \\
(4.015)\end{array}$ & $\begin{array}{l}-1.074 \\
(3.807)\end{array}$ \\
\hline$N$ & 58 & 57 & 57 & 56 \\
\hline
\end{tabular}

Notes. ${ }^{*} p<.10,{ }^{* *} p<.05,{ }^{* * *} p<.01$. As in Ashraf and Galor (2013), all regressions include geographical controls for terrain characteristics as well as OPEC, legal origin, Sub-Saharan Africa, and continent fixed effects. Heteroskedasticity-robust standard errors are reported in parentheses. 
Table 8: Costs and Benefits of Diversity. Contrasting Trust with Cooperation (ADDing YeARs of SCHOOLING AS A CONTROL VARIABle)

\begin{tabular}{|c|c|c|c|c|}
\hline & \multirow[t]{2}{*}{ Trust } & \multicolumn{3}{|c|}{ Cooperation } \\
\hline & & Taxes & Benefits & $\begin{array}{l}\text { Public } \\
\text { Transport }\end{array}$ \\
\hline $\begin{array}{l}\text { Predicted diversity } \\
\text { (ancestry adjusted) }\end{array}$ & $\begin{array}{c}-2.090^{* * *} \\
(0.736)\end{array}$ & $\begin{array}{l}6.749^{*} \\
(3.840)\end{array}$ & $\begin{array}{c}17.691^{* * *} \\
(4.245)\end{array}$ & $\begin{array}{c}14.793^{* * *} \\
(3.834)\end{array}$ \\
\hline $\begin{array}{l}\text { log Neolithic transition } \\
\text { timing (ancestry adjusted) }\end{array}$ & $\begin{array}{c}0.078 \\
(0.063)\end{array}$ & $\begin{array}{c}0.325 \\
(0.406)\end{array}$ & $\begin{array}{l}-0.339 \\
(0.360)\end{array}$ & $\begin{array}{l}-0.214 \\
(0.370)\end{array}$ \\
\hline $\begin{array}{l}\text { log percentage of } \\
\text { arable land }\end{array}$ & $\begin{array}{c}0.007 \\
(0.017)\end{array}$ & $\begin{array}{l}-0.063 \\
(0.093)\end{array}$ & $\begin{array}{c}0.041 \\
(0.108)\end{array}$ & $\begin{array}{c}0.016 \\
(0.090)\end{array}$ \\
\hline log absolute latitude & $\begin{array}{l}-0.006 \\
(0.032)\end{array}$ & $\begin{array}{c}0.273 \\
(0.313)\end{array}$ & $\begin{array}{l}-0.250 \\
(0.266)\end{array}$ & $\begin{array}{c}0.041 \\
(0.264)\end{array}$ \\
\hline Social infrastructure & $\begin{array}{c}0.130 \\
(0.091)\end{array}$ & $\begin{array}{l}-0.134 \\
(0.422)\end{array}$ & $\begin{array}{c}0.061 \\
(0.539)\end{array}$ & $\begin{array}{c}0.057 \\
(0.433)\end{array}$ \\
\hline Ethnic fractionalization & $\begin{array}{c}0.028 \\
(0.065)\end{array}$ & $\begin{array}{c}-0.842^{* *} \\
(0.414)\end{array}$ & $\begin{array}{l}-0.226 \\
(0.446)\end{array}$ & $\begin{array}{l}-0.536 \\
(0.422)\end{array}$ \\
\hline $\begin{array}{l}\text { Percentage of population at risk } \\
\text { of contracting malaria }\end{array}$ & $\begin{array}{l}-0.043 \\
(0.085)\end{array}$ & $\begin{array}{c}0.880 \\
(0.727)\end{array}$ & $\begin{array}{l}-0.316 \\
(0.657)\end{array}$ & $\begin{array}{c}0.436 \\
(0.593)\end{array}$ \\
\hline $\begin{array}{l}\text { Mean distance to } \\
\text { nearest waterway }\end{array}$ & $\begin{array}{l}-0.044 \\
(0.062)\end{array}$ & $\begin{array}{c}0.558 \\
(0.544)\end{array}$ & $\begin{array}{c}0.141 \\
(0.649)\end{array}$ & $\begin{array}{c}0.208 \\
(0.619)\end{array}$ \\
\hline $\begin{array}{l}\text { Years of } \\
\text { schooling }\end{array}$ & $\begin{array}{c}0.014 \\
(0.009)\end{array}$ & $\begin{array}{c}0.100 \\
(0.060)\end{array}$ & $\begin{array}{c}0.026 \\
(0.063)\end{array}$ & $\begin{array}{c}0.077 \\
(0.051)\end{array}$ \\
\hline Constant & $\begin{array}{c}0.960 \\
(0.603)\end{array}$ & $\begin{array}{c}0.285 \\
(3.671)\end{array}$ & $\begin{array}{l}-0.976 \\
(3.983)\end{array}$ & $\begin{array}{l}-0.984 \\
(3.542)\end{array}$ \\
\hline$N$ & 58 & 57 & 57 & 56 \\
\hline
\end{tabular}

Notes. ${ }^{*} p<.10,{ }^{* *} p<.05,{ }^{* * *} p<.01$.This table reports coefficients from the same regression as in Table 1 in the main text, but adds years of schooling as a control variable. Outcomes are qualitatively and quantitatively similar to those reported in Table 1. 
Table 9: Costs and Benefits of Diversity: Contrasting Trust with Cooperation (Alternative proxies)

\begin{tabular}{|c|c|c|c|c|}
\hline & \multirow{2}{*}{$\begin{array}{c}\text { Trust } \\
\text { Alternative } \\
\text { Trust }\end{array}$} & \multicolumn{3}{|c|}{ Cooperation } \\
\hline & & Altruism & $\begin{array}{l}\text { Negative } \\
\text { Reciprocity }\end{array}$ & $\begin{array}{l}\text { Positive } \\
\text { reciprocity }\end{array}$ \\
\hline $\begin{array}{l}\text { Predicted diversity } \\
\text { (ancestry adjusted) }\end{array}$ & $\begin{array}{l}-0.785 \\
(3.085)\end{array}$ & $\begin{array}{c}5.028 \\
(4.531)\end{array}$ & $\begin{array}{c}1.064 \\
(2.344)\end{array}$ & $\begin{array}{c}4.537 \\
(5.072)\end{array}$ \\
\hline $\begin{array}{l}\log \text { Neolithic transition } \\
\text { timing (ancestry adjusted) }\end{array}$ & $\begin{array}{l}0.330^{*} \\
(0.190)\end{array}$ & $\begin{array}{c}0.017 \\
(0.224)\end{array}$ & $\begin{array}{l}-0.105 \\
(0.174)\end{array}$ & $\begin{array}{c}0.068 \\
(0.262)\end{array}$ \\
\hline $\begin{array}{l}\text { log percentage of } \\
\text { arable land }\end{array}$ & $\begin{array}{c}-0.152^{* *} \\
(0.074)\end{array}$ & $\begin{array}{l}-0.189 \\
(0.121)\end{array}$ & $\begin{array}{c}0.134 \\
(0.088)\end{array}$ & $\begin{array}{c}-0.293^{* *} \\
(0.129)\end{array}$ \\
\hline log absolute latitude & $\begin{array}{c}0.039 \\
(0.162)\end{array}$ & $\begin{array}{l}0.326^{*} \\
(0.178)\end{array}$ & $\begin{array}{l}-0.050 \\
(0.098)\end{array}$ & $\begin{array}{c}0.207 \\
(0.126)\end{array}$ \\
\hline Social infrastructure & $\begin{array}{c}0.314 \\
(0.242)\end{array}$ & $\begin{array}{c}0.098 \\
(0.417)\end{array}$ & $\begin{array}{l}0.548^{* *} \\
(0.247)\end{array}$ & $\begin{array}{c}0.105 \\
(0.305)\end{array}$ \\
\hline Ethnic fractionalization & $\begin{array}{l}-0.113 \\
(0.262)\end{array}$ & $\begin{array}{c}-0.619^{* *} \\
(0.280)\end{array}$ & $\begin{array}{l}-0.233 \\
(0.193)\end{array}$ & $\begin{array}{l}-0.231 \\
(0.288)\end{array}$ \\
\hline $\begin{array}{l}\text { Percentage of population at risk } \\
\text { of contracting malaria }\end{array}$ & $\begin{array}{l}-0.124 \\
(0.218)\end{array}$ & $\begin{array}{c}0.005 \\
(0.246)\end{array}$ & $\begin{array}{l}-0.012 \\
(0.194)\end{array}$ & $\begin{array}{c}0.434 \\
(0.280)\end{array}$ \\
\hline $\begin{array}{l}\text { Mean distance to } \\
\text { nearest waterway }\end{array}$ & $\begin{array}{c}0.237 \\
(0.263)\end{array}$ & $\begin{array}{l}1.063^{* *} \\
(0.487)\end{array}$ & $\begin{array}{l}-0.234 \\
(0.219)\end{array}$ & $\begin{array}{l}0.694^{* *} \\
(0.315)\end{array}$ \\
\hline Constant & $\begin{array}{l}-2.105 \\
(2.047) \\
\end{array}$ & $\begin{array}{l}-4.490 \\
(2.991) \\
\end{array}$ & $\begin{array}{c}0.129 \\
(1.831) \\
\end{array}$ & $\begin{array}{l}-4.308 \\
(3.177) \\
\end{array}$ \\
\hline$N$ & 45 & 45 & 45 & 45 \\
\hline
\end{tabular}

Notes. ${ }^{*} p<.10,{ }^{* *} p<.05,{ }^{* * *} p<.01$.This table reports coefficients from the same regression as in Table 1 in the main text, but dependent variables are obtained from the dataset collected by Falk et al. (2018). Outcomes are qualitatively similar to those reported in Table 1, yet in none of the cases the coefficient of main interest is significant. 
Table 10: Individual-LeVel ANALysis BASED on SECOND GENERATiOn IMMigrants.

\begin{tabular}{|c|c|c|c|c|}
\hline & \multicolumn{2}{|c|}{ Trust } & \multicolumn{2}{|c|}{ Cooperation } \\
\hline $\begin{array}{l}\text { Predicted diversity } \\
\text { of mother's country }\end{array}$ & $\begin{array}{c}-3.798^{* * *} \\
(0.900)\end{array}$ & & $\begin{array}{c}1.047^{* * *} \\
(0.382)\end{array}$ & \\
\hline $\begin{array}{l}\text { Kinship score } \\
\text { of mother's country }\end{array}$ & & $\begin{array}{c}-0.325^{* * *} \\
(0.044)\end{array}$ & & $\begin{array}{c}0.138^{* * *} \\
(0.019)\end{array}$ \\
\hline $\begin{array}{l}\text { Sex of } \\
\text { respondent }\end{array}$ & $\begin{array}{c}-0.077^{* * *} \\
(0.023)\end{array}$ & $\begin{array}{c}-0.071^{* * *} \\
(0.023)\end{array}$ & $\begin{array}{c}0.220^{* * *} \\
(0.010)\end{array}$ & $\begin{array}{c}0.224^{* * *} \\
(0.010)\end{array}$ \\
\hline $\begin{array}{l}\text { Age of } \\
\text { respondent }\end{array}$ & $\begin{array}{c}0.003 \\
(0.003)\end{array}$ & $\begin{array}{c}0.004 \\
(0.003)\end{array}$ & $\begin{array}{c}0.007^{* * *} \\
(0.001)\end{array}$ & $\begin{array}{c}0.007^{* * *} \\
(0.002)\end{array}$ \\
\hline Has university diploma & $\begin{array}{c}0.552^{* * *} \\
(0.028)\end{array}$ & $\begin{array}{c}0.547^{* * *} \\
(0.028)\end{array}$ & $\begin{array}{l}0.030^{* *} \\
(0.012)\end{array}$ & $\begin{array}{l}0.029^{* *} \\
(0.012)\end{array}$ \\
\hline $\begin{array}{l}\text { Mother has } \\
\text { university diploma }\end{array}$ & $\begin{array}{c}0.122^{* * *} \\
(0.039)\end{array}$ & $\begin{array}{c}0.128^{* * *} \\
(0.040)\end{array}$ & $\begin{array}{c}-0.041^{* *} \\
(0.018)\end{array}$ & $\begin{array}{c}-0.035^{* *} \\
(0.018)\end{array}$ \\
\hline $\begin{array}{l}\text { Father has } \\
\text { university diploma }\end{array}$ & $\begin{array}{c}0.223^{* * *} \\
(0.035)\end{array}$ & $\begin{array}{c}0.218^{* * *} \\
(0.035)\end{array}$ & $\begin{array}{c}0.018 \\
(0.015)\end{array}$ & $\begin{array}{c}0.019 \\
(0.015)\end{array}$ \\
\hline $\begin{array}{l}\text { Feeling } \\
\text { towards income }\end{array}$ & $\begin{array}{c}-0.346^{* * *} \\
(0.015)\end{array}$ & $\begin{array}{c}-0.336^{* * *} \\
(0.015)\end{array}$ & $\begin{array}{l}-0.003 \\
(0.006)\end{array}$ & $\begin{array}{l}-0.007 \\
(0.006)\end{array}$ \\
\hline $\begin{array}{l}\text { Size of } \\
\text { the household }\end{array}$ & $\begin{array}{c}0.012 \\
(0.009)\end{array}$ & $\begin{array}{l}0.015^{*} \\
(0.009)\end{array}$ & $\begin{array}{c}0.035^{* * *} \\
(0.004)\end{array}$ & $\begin{array}{c}0.033^{* * *} \\
(0.004)\end{array}$ \\
\hline Unemployed & $\begin{array}{l}-0.086^{*} \\
(0.050)\end{array}$ & $\begin{array}{c}-0.099^{* *} \\
(0.050)\end{array}$ & $\begin{array}{c}0.034^{*} \\
(0.020)\end{array}$ & $\begin{array}{c}0.021 \\
(0.021)\end{array}$ \\
\hline $\begin{array}{l}\text { Living in } \\
\text { rural areas }\end{array}$ & $\begin{array}{l}-0.007 \\
(0.024)\end{array}$ & $\begin{array}{l}-0.025 \\
(0.024)\end{array}$ & $\begin{array}{c}0.003 \\
(0.010)\end{array}$ & $\begin{array}{c}0.010 \\
(0.010)\end{array}$ \\
\hline Constant & $\begin{array}{c}6.553^{* * *} \\
(0.743)\end{array}$ & $\begin{array}{c}3.903^{* * *} \\
(0.424)\end{array}$ & $\begin{array}{c}1.668^{* * *} \\
(0.299)\end{array}$ & $\begin{array}{c}2.350^{* * *} \\
(0.118)\end{array}$ \\
\hline$N$ & 40,306 & 39,254 & 39,473 & 38,441 \\
\hline
\end{tabular}

Notes. ${ }^{*} p<.10,{ }^{* *} p<.05,{ }^{* * *} p<.01$. The regression uses all available rounds of the European Social Survey, from 2002 to 2016. Individuals have been interviewed in 34 different countries. We retain only second generation immigrants. 